\title{
Abiotic variables accounting for presence of the exotic rainbow trout (Oncorhynchus mykiss) in Eastern Quebec Rivers
}

\author{
I. Thibault( ${ }^{(1,2)}$, R.D. Hedger ${ }^{(1,3)}$, H. Crépeau ${ }^{(4)}$, C. Audet ${ }^{(5)}$, J.J. Dodson ${ }^{(1)}$
}

Received April 5, 2010 / Reçu le 5 avril 2010

Revised July 28, 2010 / Révisé le 28 juillet 2010

Accepted August 2, 2010 / Accepté le 2 août 2010

\section{ABSTRACT}

Key-words: $\quad$ Rainbow trout is an exotic fish species that has been introduced in Quebec invasion success, abiotic filter, River

geomorphological In this study, the relationship between rainbow trout occurrence (presence variables, climatic variables, logistic regression modelling (Canada) since 1893-1894. Despite spatially-restricted stocking for recreational fishing, the species has spread throughout the Saint Lawrence or absence) and abiotic variables (river geomorphology and climate) was examined for 91 coastal rivers throughout Eastern Quebec in order to determine which variables promote or impede the ongoing invasion process. Results revealed that rainbow trout presence in Eastern Quebec was primarily determined by geomorphological parameters. The invader's presence was strongly related to the presence of tributaries (especially larger ones). To a lesser extent, the presence of rainbow trout was positively related to warm spring and summer temperatures and negatively related to the peak flood date occurring during the egg deposition period (May).

This study proposes a parsimonious modelling approach to identify which environmental parameters favour the spreading of an invader, even when a limited dataset is available due to the incomplete invasion process.

\section{RÉSUMÉ}

Variables abiotiques expliquant la présence d'une espèce exotique, la truite arc-en-ciel (Oncorhynchus mykiss), dans les rivières de l'Est du Québec
Mots-clés :
La truite arc-en-ciel est un poisson exotique qui a été introduit au Québec succès
d'invasion, filtre abiotique, variables (Canada) en 1893-1894. Malgré un zonage piscicole restreignant spatialement son ensemencement à des fins de pêche sportive, l'espèce s'est dispersée le long du fleuve Saint-Laurent.
Dans cette étude, la relation entre l'occurrence de la truite arc-en-ciel (présence ou géomorpho- logiques, absence) et des variables abiotiques (géomorphologie fluviale et climat) a été exa- minée pour 91 rivières côtières situées dans l'Est du Québec, afin de déterminer

(1) Département de biologie, Québec-Océan, Université Laval, Québec, QC, G1V 0A6, Canada, isabel.thibault.2@ulaval.ca

(2) Present address: Ministère des ressources naturelles et de la faune, Direction de l'expertise sur la faune et ses habitats, 880 chemin Sainte-Foy, $2^{e}$ étage, Québec, QC, G1S 4X4, Canada, isabel.thibault@mrnf.gouv.qc.ca

(3) Present address: Norwegian Institute for Nature Research, 7485 Trondheim, Norway

(4) Département de mathématiques et de statistique, Université Laval, Québec, QC, G1V OA6, Canada

(5) Institut des sciences de la mer de Rimouski (ISMER-UQAR), Université du Québec à Rimouski, Rimouski, QC,

G5L 3A1, Canada 
variables climatiques, modèle de régression logistique quelles variables promeuvent ou limitent le processus d'invasion actuellement en cours.

Les résultats indiquent que la présence de la truite arc-en-ciel dans l'Est du Québec était principalement déterminée par des paramètres géomorphologiques. La présence de l'envahisseur était fortement associée à la présence de tributaires (principalement les plus gros). Dans une moindre mesure, la présence de la truite arc-en-ciel était positivement reliée à des températures printanières et estivales élevées, et négativement associée à la date de crue qui survient durant la période de dépôt des œufs (mai).

Cette étude propose une approche de modélisation parcimonieuse qui permet d'identifier quels paramètres environnementaux favorisent la dispersion d'un envahisseur, même si on ne dispose que de données fragmentaires en raison d'un processus d'invasion non complété.

\section{INTRODUCTION}

Rainbow trout ${ }^{1}$ (Oncorhynchus mykiss, Walbaum, 1792), originating from the North Pacific coastline, is currently found in watercourses on all continents, except Antarctica (Cambray, 2003). In Canada, it was first introduced in 1881 in the Great Lakes Basin. Eggs were first imported to the province of Quebec in 1893-1994 (MacCrimmon, 1971). Following repeated and massive stockings, the species now reproduces in the Great Lakes, Lake Memphrémagog and probably some tributaries located in the vicinity of Montreal (Mongeau et al., 1980; Dumont, 1991; Kerr and Lasenby, 2000). In Quebec, stocking and farming of rainbow trout is limited to the upper region of the Saint Lawrence River (MAPAQ, 2005; Figure 1). However, the species has been captured in many tributaries in the downstream part of the Saint Lawrence River and its estuary since 1973 (Whoriskey et al., 1981; Dumont et al., 1988). Captures of rainbow trout, especially adults, are now frequently recorded along the Gaspesian coast and the lower Saint Lawrence shore (Bas-St-Laurent) as well as in the Charlevoix region. Selfsupporting populations have been identified in four rivers in these regions (Thibault et al., $2009,2010)$. Although globally there have been a large number of failed attempts to introduce rainbow trout (MacCrimmon, 1971; Fausch, 1988, 2007), it appears that the species is slowly colonizing rivers throughout Eastern Quebec.

The success of biological invasions depends on the invader's capacity to pass through a series of hierarchical filters associated with the different stages of the invasion process (introduction, establishment, spreading). The success of introduction depends on survival during transit between the native habitat and the new environment (Kolar and Lodge, 2001) and the number of introduction events and introduced individuals (Colautti and Maclsaac, 2004; Moyle and Marchetti, 2006). As such, distance from the source populations may be a significant predictor of establishment success, with habitats located closer to source populations being the most likely to be colonized.

The success of establishment also depends on the species ability to survive in the face of abiotic resistance through either acclimatisation or adaptation to novel physical conditions (Williamson, 1996; Quist et al., 2005; Moyle and Marchetti, 2006), and the species ability to survive in the face of biotic resistance exerted by the native fauna (Laurenson and Hocutt, 1985; Quist et al., 2005). Finally, the success of spreading to new environments depends on the reproductive and dispersive capacities of the species (Laurenson and Hocutt, 1985; Kolar and Lodge, 2001; Colautti et al., 2006; Richards et al., 2006).

Abiotic conditions in the receiving environment generally constitute the most important filter (Moyle and Light, 1996). In Eastern Quebec, it seems likely that the rainbow trout colonization process is driven in part by the river's morphology, as a river's attractiveness for rainbow trout may depend on characteristics such as slope, elevation, channel dimensions, accessibility and the presence of tributaries. Slope and elevation strongly influence the spatial distribution

\footnotetext{
1 The term "rainbow trout" is used for both resident and anadromous (steelhead) forms.
} 


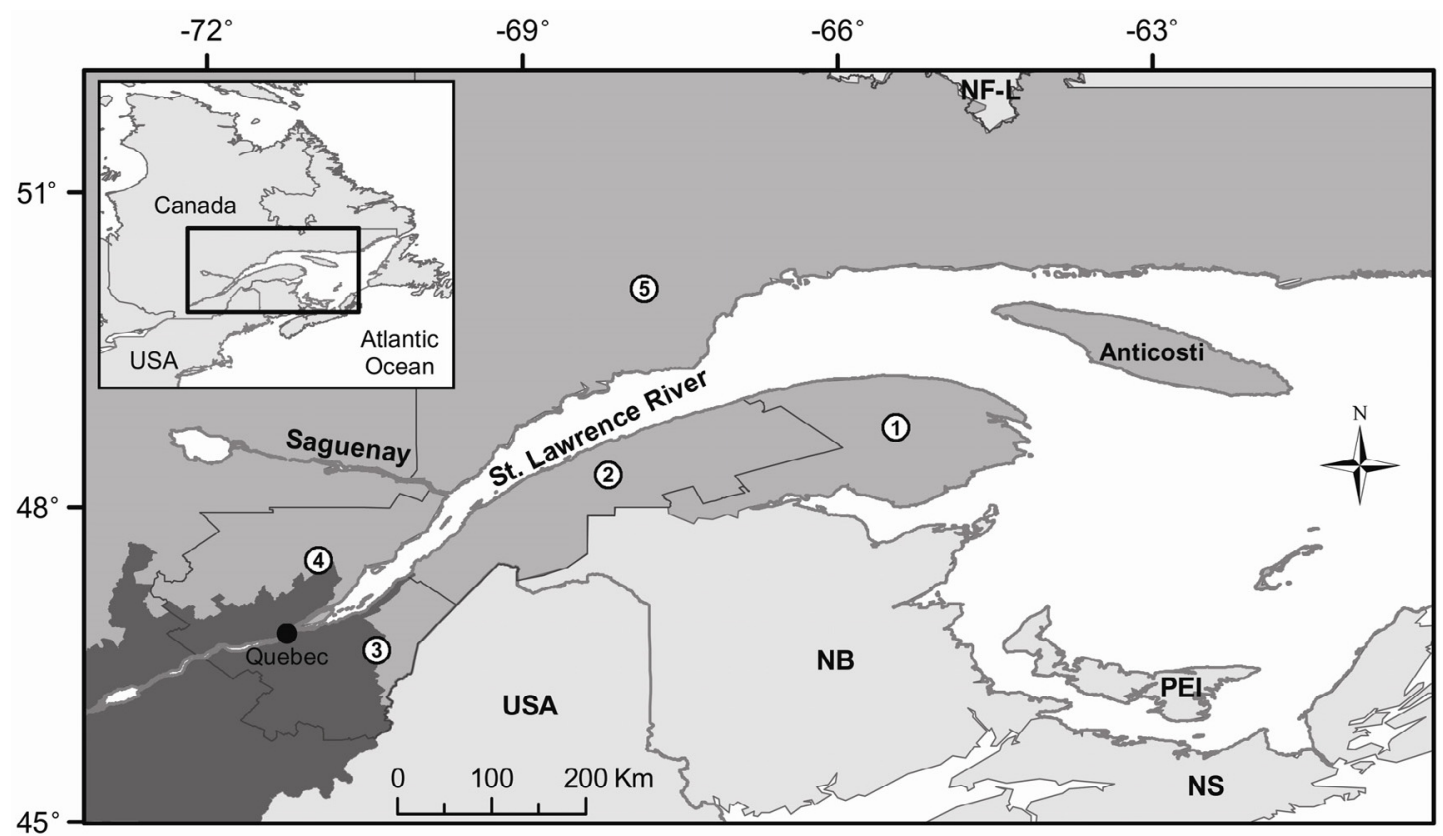

\section{Figure 1}

Study area in Eastern Quebec (Canada). Quebec province is in medium grey. Rainbow trout stocking area is in dark grey. 1: Gaspesia, 2: Bas-St-Laurent, 3: Chaudière-Appalaches, 4: Capitale-Nationale (including Charlevoix region), 5: Côte-Nord. NB: New Brunswick, NS: Nova Scotia, PEl: Prince Edward Island, NF-L: Newfoundland-Labrador.

\section{Figure 1}

Aire d'étude dans l'est du Québec (Canada). La province de Québec est en gris pâle. La région où la truite arc-en-ciel peut être ensemencée est indiquée en gris foncé. 1 : Gaspésie, 2 : Bas-St-Laurent, 3 : Chaudière-Appalaches, 4 : Capitale-Nationale (incluant la région de Charlevoix), 5 : Côte-Nord. NB : Nouveau-Brunswick, NS : Nouvelle-Écosse, PEl : Île-du-Prince-Édouard, NF-L : Terre-Neuve-Labrador.

of rainbow trout, with densities being higher in downstream areas where elevation and slope gradients are less (Gard and Flittner, 1974). The distribution of this species along an altitudinal gradient may be attributed to changes in current velocity, pool to riffle ratio, substrate size, and temperature variations. Slope, sinuosity and channel length also influence the flow regime and can modulate flood amplitude. The presence of dams will impede upstream movement of rainbow trout, whereas tributaries could provide safe habitats for eggs and juveniles.

The establishment of new populations will also depend on the local climatic conditions (temperature, precipitation and flood regime). Rainbow trout is adapted for cold-temperate environments but can tolerate warm temperatures, with critical thermal maxima in the vicinity of 28-30 ${ }^{\circ} \mathrm{C}$ (Currie et al., 1998). The optimal temperature varies from 10 to $21^{\circ} \mathrm{C}$ according to life-stage (Garside and Tait, 1958; Burgner et al., 1992; Lefler et al., 2006; Boughton et al., 2007; Nelitz et al., 2007). Discharge and the timing of peak flows, dependent on precipitation, also play an important role in defining suitable habitat for rainbow trout. The abundance of 0 -aged rainbow trout may be positively related to winter and spring river discharge (Mitro et al., 2003). Given that rainbow trout reproduce in spring, floods induced by snow melting may destroy nests and wash away eggs. Fausch et al. (2001) found that the worldwide establishment success of rainbow trout is closely related to the concordance of fry emergence and months of low flood probability.

The main objective of this study was thus to determine which abiotic factors explain the presence of rainbow trout in the rivers of Eastern Quebec. To do so, we identified the variables characterising the geomorphology, temperature, hydrology and precipitation regime of those rivers in which rainbow trout occur relative to those rivers where no trout have been detected. 
Insufficient data concerning water quality (e.g. pH, conductivity, and dissolved nutrient concentrations) precluded their inclusion in this analysis. Our initial hypothesis was that distance from the stocking area, river slope, temperature during the growing season, and the flood regime associated with spring precipitations would be the most important parameters influencing rainbow trout presence. Biotic resistance was not considered in this analysis as the distribution of the two species most likely to impede rainbow trout establishment, Atlantic salmon (Salmo salar) and brook charr (Salvelinus fontinalis), is ubiquitous at the spatial scale of this study. Multispecific interactions at smaller spatial scales are the subject of a parallel study (Thibault, 2010).

\section{MATERIALS AND METHODS}

\section{$>$ STUDY AREA}

Eastern Quebec $\left(\sim 46.5-52^{\circ} \mathrm{N}, \sim 70-60^{\circ} \mathrm{W}\right)$ bounds the Saint Lawrence Estuary (Figure 1) in eastern Canada. It is characterized by a cold-temperate climate, with mean coastal temperatures typically ranging between less than $-12{ }^{\circ} \mathrm{C}$ in January and greater than $16{ }^{\circ} \mathrm{C}$ in July. Effective growing degree days (EGDD) above $5^{\circ} \mathrm{C}$ range from approximately 1700 in the south to 900 in the north. Water coastal temperatures are influenced by currents within the estuary - a warm current extends along the North Shore between Quebec City and the Saguenay Fjord crossing to the South Shore at the confluence with the Saguenay Fjord. To the east of the Saguenay, temperatures along the North Shore tend to be less than those on the South Shore. Mean precipitation along the coast varies between approximately 800 and $1200 \mathrm{~mm} \cdot \mathrm{y}^{-1}$.

\section{> RAINBOW TROUT DATA}

Rainbow trout occurrence was only considered for rivers located to the east of the zone where stocking has been permitted (i.e. rivers where rainbow trout have not been artificially introduced). Rainbow trout data were obtained from three sources: (i) the Ministère des ressources naturelles et de la faune (MNRF); (ii) commercial and sport fishing organizations and (iii) electrofishing surveys performed in 2007. Data recorded by MRNF, which constituted the major part of our rainbow trout database, were found in internal reports, scientific papers, fish record databases and more recently, in fishing survey datasets. The latter mainly consisted of electrofishing surveys performed periodically in rivers to monitor juvenile Atlantic salmon densities, and occasionally in non-salmon rivers (such as in Chaudière-Appalaches) for fish species inventories. Presence of rainbow trout was also registered during annual visual counts of salmon spawners. Moreover, a variety of capture devices (rotary trap, counting fence, migratory pass, etc.) are installed on several rivers to study the downstream migration Atlantic salmon smolt and the adult spawning migration. All captured rainbow trout are recorded. Commercial fishers have also been a source of information for MRNF for many years. Sport fishermen are not obliged to report rainbow trout and their input to the database has been sparse until recently. Increasing awareness concerning the invasion of rainbow trout has reversed this tendency, particularly within salmon sport fishing organizations (e.g. under the ZEC "controlled exploitation zone" management framework). To further increase the contributions of the sport fishery to the database, we invited sport fishers in 2006 and 2007 to record all their rainbow trout captures in targeted ZEC and MRNF offices. Finally, electrofishing surveys (about 10 to 20 open stations per river, parcel size of $100 \mathrm{~m}^{2}$, separated by $1 \mathrm{~km}$, two passes) of rainbow trout juveniles were performed in 2007, providing further information on rainbow trout incidence in eight targeted rivers.

In total, more than 3300 records of rainbow trout have been registered in Eastern Quebec (Capitale-Nationale, Côte-Nord, Chaudière-Appalaches, Bas-St-Laurent and Gaspesia regions, Figure 1). More than $50 \%$ of records have been reported since 1999. Variation observed 


\section{Table I}

Thirty-five geomorphological and climatic variables used in the analysis, grouped into compartments used for modelling.

\section{Tableau}

Trente-cinq variables géomorphologiques et climatiques utilisées dans les analyses, regroupées selon les contingents utilisés pour la modélisation.

\begin{tabular}{lc}
\hline Variables & Abbreviation \\
\hline $\begin{array}{c}\text { Geomorphological variables } \\
\text { Initial mean slope }\end{array}$ & MS \\
Sinuosity & Sin \\
Minimum elevation & MinE \\
Maximum elevation & MaxE \\
River length & Len \\
Number of large tributaries & LTrib \\
Number of small tributaries & STrib \\
Presence of a dam & Dam \\
Distance from the stocking zone & SZD \\
& \\
Climatic variables & \\
Temperature & \\
Mean monthly water temperature $(n=12)$ & T_Jan to T_Dec \\
Effective growing degree days $\left(>5^{\circ} \mathrm{C}\right)$ & EGDD \\
Precipitation & \\
Total monthly precipitation $(n=12)$ & P_Jan to P_Dec \\
Peak flood date & PFD \\
\hline
\end{tabular}

in the number of rainbow trout registered per river (one record up to several hundred) is not only explained by the spatial distribution of the species. It also relies on fishing effort, which varies between rivers according to the rivers' accessibility and attractiveness for fishers, and to the monitoring efforts of managers. Given that data quality varied according to data source (ranging from rivers with a single reference indicating the presence of rainbow trout to rivers having detailed surveys of the spatial variation in rainbow trout abundance), and that we could not control for fishing effort, data standardization was necessary. The binary variable rainbow trout occurrence was therefore established (with two options: "present" or "absent"). Rainbow trout was scored as being present within a river if there was any observation or capture in that river within the dataset. Otherwise, rainbow trout was scored as being absent. This was based on the assumption that the situation where other captures occurred, but were not registered by sport fishers, was a far more likely scenario than the situation where the only rainbow trout ever to enter the river had been captured and registered. To limit the situation where rainbow trout were present but not scored as such because of limited fishing effort or no registration, all rivers from remote regions were removed from the study: (i) rivers north of $50.25^{\circ} \mathrm{N}$ and east of $66.5^{\circ} \mathrm{W}$ along the Côte-Nord, (ii) rivers east of $63.4^{\circ} \mathrm{W}$ on Anticosti Island, and (iii) rivers distant from the coast. Finally, we analysed a subset of rivers to assess the potential bias of variable fishing effort in modelling relationships between rainbow trout presence and environmental factors (see below).

\section{$>A B I O T I C$ DATA}

Abiotic data were acquired on river geomorphology and climate (a list of abbreviations for the abiotic variables is presented in Table I).

\section{Geomorphological variables}

Mean channel slope (MS) was determined for the most downstream $20 \mathrm{~km}$ of the principal channel (or the total length of the principal channel if this length was less than $20 \mathrm{~km}$ ). 
Minimum and maximum channel elevations (MinE and MaxE) were estimated on the total length of the main watercourses by integrating a DEM (Canadian Digital Elevation Data, obtained from GeoBase, www.geobase.ca) with the coordinates of each channel (MRNF (Québec, 2000)). Sinuosity (Sin) was estimated as the ratio of the along-channel distance to the Euclidean distance from the river mouth to a position along the principal channel $20 \mathrm{~km}$ upstream (or the most upstream part of the watercourse if the total channel length (Len) was less than $20 \mathrm{~km}$ ). The number of tributaries that flowed into the principal channel was enumerated at two spatial scales: larger tributaries (LTrib) at a scale of 1:1000 000 ("hydro_I_arc" MRNF shapefile (Québec, 2000)) and smaller tributaries such as creeks or intermittent streams (STrib) at a scale of 1:50 000 ("QCmnwtl" Canadian hydrographic network shapefile (DMTI Spatial, 2005)). We estimated an error of \pm 5 in the count of small tributaries. The number of dams (Dam) greater than $2 \mathrm{~m}$ in height within the downstream $10 \mathrm{~km}$ of each river was estimated using data obtained from the Centre d'expertise hydrique du Québec. For rivers along the North and South Shore of the Saint Lawrence, the distance from the stocking zone (SZD) in southern Quebec (Figure 1) was estimated along the coastline. For rivers on Anticosti Island, distance was estimated from the stocking zones along the coast to the apex of the Gaspesian peninsula, plus a Euclidean distance between this apex and the island, plus a distance around the island to the rivers in question. A rainbow trout aquaculture industry and naturalized populations also exist in the Maritime Provinces, but these populations are not a significant source of trout in the St. Lawrence study area (Thibault et al., 2009).

\section{Climatic variables}

Climatic data were obtained from the Canadian Weatheroffice (1971-2000 Canadian Climate Normals, www.climate.weatheroffice.ec.gc.ca). These data included 30-year means of monthly temperatures and total monthly precipitation $(P)$ for 430 weather stations throughout Quebec. Climatic variables only showed climate properties at the weather stations, and not at the rivers where rainbow trout presence had been evaluated. Variograms were used to establish the spatial dependence in climatic variables, and kriging was used to estimate climate variables at the river mouths, using the sgeostats package developed by J.J. Majure and A. Gebhardt in R (Hornik, 2007). River water temperature was estimated from air temperature using a non-parametric regression relationship established between water and air temperature for selected rivers where concurrent data were available. Water temperatures were obtained from thermograph data collected in 26 rivers throughout Quebec by the MRNF. The temporal ranges of these thermograph data varied according to river, but most data were obtained from 2001-2005, so data from outside of this time range were removed. The relationship between daily median water temperature (the response variable) and (i) daily median air temperature, (ii) longitude and (iii) latitude was determined using generalized additive modelling (Hastie and Tibshirani, 1990). Using the three predictors, the generalized additive model explained $86.2 \%$ of the variance in daily median water temperature. The generalized additive model was then used to predict mean water temperature as a function of day of the year in all rivers, using the kriged estimate of air temperature at the river, river latitude and river longitude. Latitude and longitude were included as predictors because the relationship between air temperature and water temperature varied spatially. Means of monthly water temperature $(T)$ and effective growing degree days (EGDD, the sum of the difference between mean daily temperature and $5{ }^{\circ} \mathrm{C}$ ) were calculated from these estimated daily values. Finally, peak flood date (PFD) in each river was estimated from a hydrographic database amassed by the Centre d'expertise hydrique du Québec which contained data from hydrographic stations in 38 rivers. The spatial dependence in PFD of the hydrograph data was modelled using variograms, and kriging was used to interpolate PFD for each river in the current study. Kriging meant that the estimated PFD for each river was a weighted function of neighbouring hydrograph PFDs (the weight being an inverse function of distance of separation). The rationale for use of kriging was that PFD was dependent on the local climate, so neighbouring rivers would have had similar PFDs. 


\section{> MODELLING THE RELATIONSHIPS}

In this section, we briefly present the approach used for modelling the relationship between rainbow trout presence and the geomorphological and the climatic variables separately (Table I), using logistic regression models (SAS v9, 2001). Models were fitted based on original variables (geomorphological data only) or on the principal components (PCs) of a principal component analysis (PCA). The use of regressions based on PCA products was justified by the presence of a large number of correlated variables, especially among climatic variables.

For original variables, tests for potential inclusion in the multivariate model were F-tests, Student tests and the Hosmer and Lemeshow (1989) criteria ( $p$-value less than 0.25 , see Appendix A). The criterion for inclusion of a PC was that it had an eigenvalue greater than 1 . Variable transformations (either by $\chi^{2}$ for a quadratic relationship, or categorization) were applied when the relationship with the logit was not linear (Appendix A).

The large number of variables in the dataset necessitated the use of an automatic selection procedure (stepwise, with entry and stay level fixed at 0.10 ) to identify the most parsimonious models. Associated statistics, such as AICc, max-rescaled- $R^{2}$, and percentage of correct classifications were calculated for each model.

As we had a single set of data, it was not possible to do cross-validation with a second dataset to test our models. We therefore included a leave-one-out cross-validation method (ctable option available in the SAS logistic procedure) in the logistic models.

\section{> INFLUENCE OF THE DETECTABILITY IN THE MODELS}

The probability of rainbow trout detection is expected to be higher in rivers where there is more monitoring and/or more sports fishing. Thus, the apparent absence of rainbow trout in some rivers may be explained by the absence of fishing in these rivers. However, as the variation in fishing and monitoring efforts among rivers was unknown, it was not possible to estimate the detection probabilities among all capture sites. A conventional way to deal with this potential bias would have been to perform occupancy models (MacKenzie et al., 2006), but the way data were collected over years did not allow us to use this approach. Instead, we conducted analyses on a subset $(n=44)$ of the rivers. For these salmon rivers, we knew the number of salmon fishing-days per year and/or where there was an annual salmon count (by fence or by snorkelling). These detection-effort variables (fishing and monitoring efforts) were included in the selected multivariate models based on abiotic variables (Appendix B) in order to determine their contribution to rainbow trout presence. Although detection effort was not targetted on rainbow trout, we considered that the probability of detecting rainbow trout would increase as a function of the number of days of sport fishing and hence potentially bias the relationship between rainbow trout presence and environmental characteristics.

\section{RESULTS}

\section{> SPATIAL DISTRIBUTION OF RAINBOW TROUT}

In total, 91 rivers were retained for analysis, including 36 rivers in which rainbow trout were reported. The spatial distribution of rainbow trout is shown in Figure 2. The species was found throughout Eastern Quebec, on both the North and South Shores of the Saint Lawrence Estuary. Rainbow trout was only observed in one river on Anticosti Island (Jupiter). Almost all captures were adults, usually caught in the river mouths or in the downstream part of the rivers. Young-of-the-year (YOY) rainbow trout were found in four rivers (Du Gouffre, Malbaie, Grands Méchins and Matane). This constitutes the only documented evidence for natural reproduction outside the stocking zones in Quebec. Of these four rivers, a higher presence of juvenile rainbow trout was found in tributaries (present in $56 \%$ of the 18 sampled stations) than in the principal channel (present in $16 \%$ of the 56 sampled stations). 


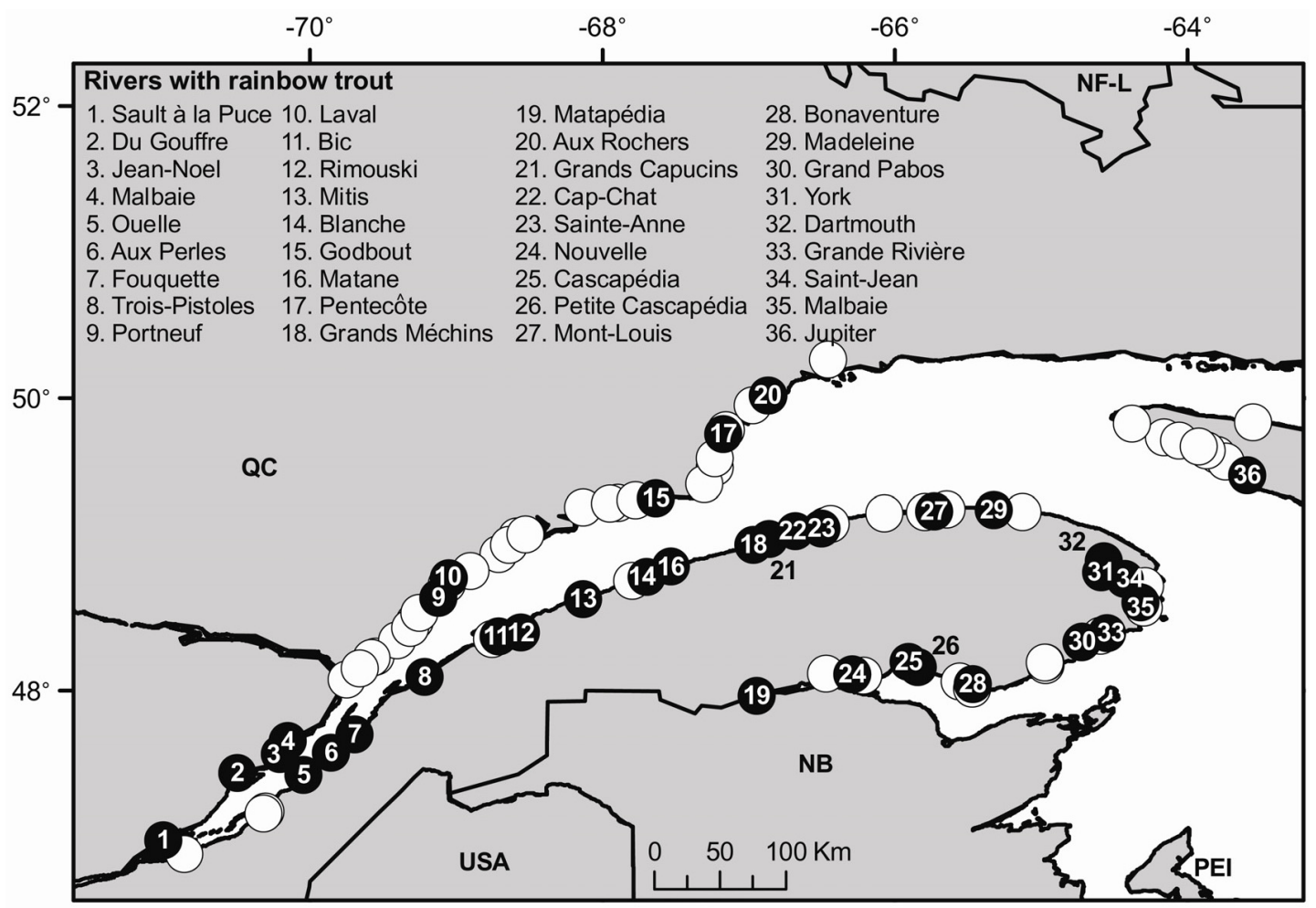

Figure 2

Spatial distribution of rivers used in the modelling of rainbow trout presence in Eastern Quebec. White circles represent rivers $(n=55)$ where rainbow trout has not been found. Black circles represent rivers where rainbow trout has been found $(n=36)$. QC: Quebec, NB: New Brunswick, NF-L: NewfoundlandLabrador, PEl: Prince Edward Island.

\section{Figure 2}

Distribution spatiale des rivières utilisées pour modéliser la présence de la truite arc-en-ciel dans l'est du Québec. Les cercles blancs représentent les rivières $(n=55)$ où la truite arc-en-ciel n'a pas été détectée. Les cercles noirs représentent les rivières où la truite arc-en-ciel a été observée $(n=36)$. QC Québec, NB : Nouveau-Brunswick, NF-L : Terre-Neuve-Labrador, PEl : Île-du-Prince-Édouard.

\section{> RELATIONSHIP BETWEEN RAINBOW TROUT PRESENCE AND ABIOTIC VARIABLES}

Geomorphological variables explained nearly half the variation in the presence of rainbow trout in Eastern Quebec. The explanatory power of the climatic variables was clearly lower, explaining less than $10 \%$ of the observed variation (Table II). Moreover, when both categories of variables were fitted into a final model, only geomorphological variables accounted for the observed variation (data not shown).

Tributaries and the first principal component (PC1) were the only variables selected by the stepwise procedure among the geomorphological models (Table II). Coefficients of the regressions based on original variables revealed that the presence of rainbow trout in a river is strongly related to the presence of large tributaries, whereas $p$-values indicated that the importance of small tributaries is lower than that of larger ones. The first principal component, explaining $33 \%$ of the variation, was strongly associated with the presence of tributaries and the river length (Figure $3 \mathrm{~A}$ ).

For the climatic model, only the first principal component was retained by the stepwise procedure (Table II). The relation between the principal component and the presence of rainbow trout was marginally significant $(p=0.05)$. The selected PCA axis (PC1, explaining $48 \%$ of 


\section{Table II}

Variables used and selected by the models, coefficients and associated statistics. Variable abbreviations are described in Table I. "Type" indicates whether the logistic regression was based on original variables or on principal components of a principal component analysis. The most significant geomorphological models are shaded. Categories of the LTrib variable are: no tributary [0], 1 or 2 tributaries [1-2], and 3 or more tributaries [3+].

\section{Tableau II}

Variables utilisées et sélectionnées par les modèles, coefficients et statistiques associées. Les abréviations des variables sont présentées dans le Tableau I. "Type » indique si la régression logistique était basée sur les variables originales ou sur les composantes principales des analyses en composantes principales. Les modèles géomorphologiques les plus significatifs sont ombragés. Les catégories pour la variable LTrib sont : aucun tributaire [0], 1 ou 2 tributaires [1-2] et 3 tributaires ou plus [3+].

\begin{tabular}{|c|c|c|c|c|c|c|c|c|}
\hline \multirow{2}{*}{\begin{tabular}{|l|} 
Model \\
ID
\end{tabular}} & \multirow{2}{*}{ Type } & \multirow{2}{*}{ Initial model } & \multicolumn{2}{|c|}{ Model statistics } & \multirow{2}{*}{\begin{tabular}{|c|}
$\%$ correct \\
classifications
\end{tabular}} & \multicolumn{3}{|c|}{ Selected variables } \\
\hline & & & \begin{tabular}{|l|} 
AlCc \\
\end{tabular} & Max-r-R ${ }^{2}$ & & Name & $p$-value & $\beta$ estimate (SE) \\
\hline \multicolumn{9}{|c|}{ Geomorphological variables } \\
\hline G1 & Originala $^{\mathrm{a}}$ & $\begin{array}{l}\text { MS MS }{ }^{2} \text { MaxE } \\
\text { Len STrib and LTrib }\end{array}$ & 85.64 & 0.49 & 85.7 & LTrib & $<0.01$ & $0.95(0.20)$ \\
\hline \multirow[t]{2}{*}{$\mathrm{G}_{2}$} & Original $^{\mathrm{a}}$ & \begin{tabular}{|c|} 
MS MS MaxE \\
Len STrib and LTrib $[0 / 1-2 / 3+]$
\end{tabular} & 87.41 & 0.49 & 80.2 & LTrib [1-2 vs. 0] & 0.02 & $1.57(0.68)$ \\
\hline & & & & & & LTrib [3+ vs. 0] & $<0.01$ & $3.72(0.73)$ \\
\hline G3 & Original $^{a}$ & $\begin{array}{c}\text { MS MS }^{2} \text { MaxE } \\
\text { Len STrib and LTrib [0/1+] }\end{array}$ & 90.21 & 0.46 & 79.1 & \begin{tabular}{|c|} 
STrib \\
LTrib $[1+v s .0]$
\end{tabular} & $\begin{array}{r}0.04 \\
<0.01\end{array}$ & $\begin{array}{l}0.02(0.01) \\
2.07(0.60)\end{array}$ \\
\hline G4 & PCA & PC1 PC2 PC3 and PC4 & 95.07 & 0.39 & 83.5 & PC1 & $<0.01$ & $0.87(0.20)$ \\
\hline \multicolumn{9}{|c|}{ Climatic variables } \\
\hline C1 & PCA & PC1 PC2 PC3 and PC4 & 122.38 & 0.06 & 64.8 & PC1 & 0.05 & $0.12(0.06)$ \\
\hline
\end{tabular}

a Sin, MinE and Dam were excluded according to Hosmer and Lemeshow criterion.

the variation) was strongly associated with temperature from April to September and to degree days, and negatively related to peak flood date (Figure 3B).

Although there was a positive significant relationship between the presence of rainbow trout and the detection (monitoring and fishing) effort prevaling in the subset of 44 rivers, when included in the two most significant geomorphological models, this variable was not significant (results presented in Appendix B). We thus considered that fishing and monitoring efforts did not significantly influence the relationships between trout presence and the abiotic characteristics included in this analysis.

\section{DISCUSSION}

\section{> GEOMORPHOLOGICAL AND CLIMATIC CONTROLS ON THE PRESENCE OF RAINBOW TROUT}

Geomorphological variables influenced the distribution of rainbow trout within Eastern Quebec to such an extent that no climatic variable was selected in the final models. The number of tributaries (especially large ones) is the most important variable affecting rainbow trout presence. Tributaries may offer slower current speeds, less severe flooding, and more cover than the principal channel, providing a more suitable environment for juveniles (Molony, 2001). Tributaries may also provide important coolwater refuges for rainbow trout during their spawning migration (High et al., 2006). Tributaries may also increase the complexity of the principal channel, in terms of changes in current speed, depth and substrate size, offering a range of habitat types which can satisfy the changes in requirements of rainbow trout at different life-stages. 
A) Geomorphological variables (G4) - PC1 (33\%)

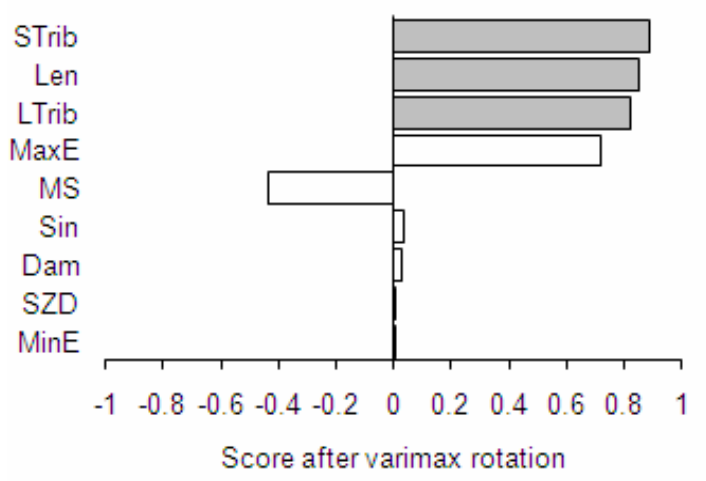

B) Climatic variables (C1) - PC1 (48\%)

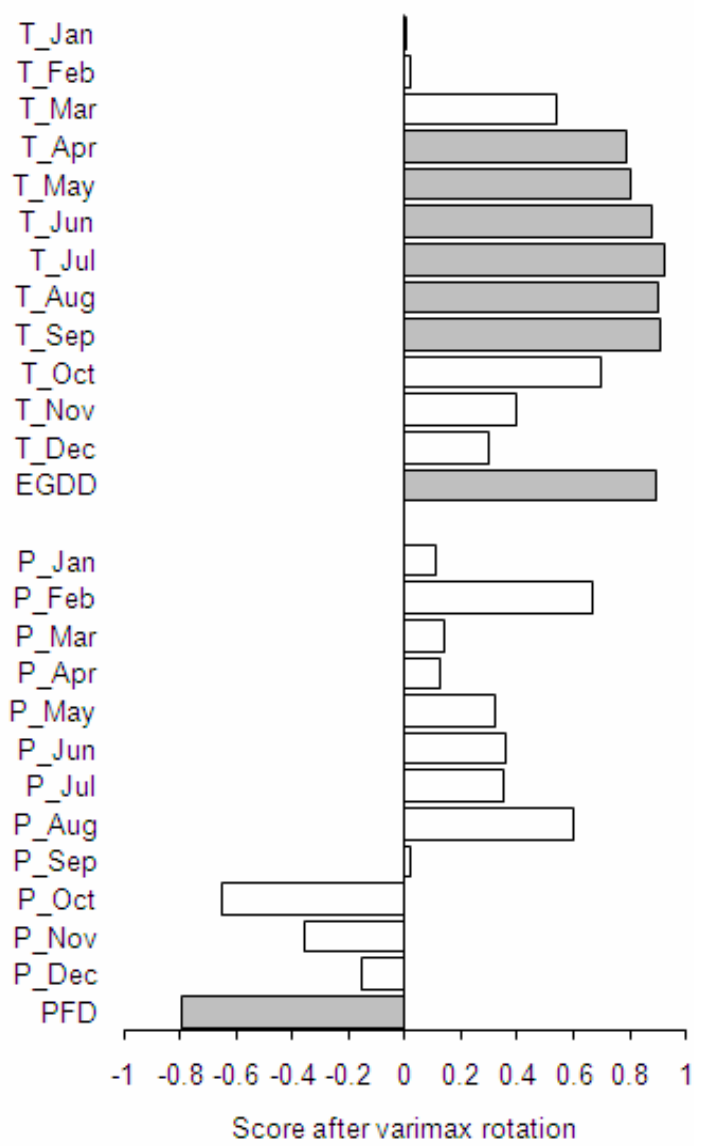

\section{Figure 3}

Scorings (after varimax rotation) on the selected principal components of the models based on A) geomorphological variables, and B) climatic variables. Significant scorings are shown by filled bars.

\section{Figure 3}

Score (après rotation varimax) des composantes principales sélectionnées par les modèles basés sur A) les variables géomorphologiques et B) les variables climatiques. Les scores significatifs sont identifiés par des bandes grises.

The number of tributaries had a far stronger influence on the presence of rainbow trout than the initial slope of the river. We found a slight but significant correlation between the number of large tributaries and mean initial slope ( $r_{\text {Pearson }}=-0.48, p<0.01$, data not shown), indicating that rivers with gentle gradients tended to have several tributaries. However, the inclusion in the models of an interaction term between initial slope and the number of tributaries (large or small) did not account for any additional variation (results not shown). As such, the importance of slope documented by Gard and Flittner (1974) might have been an artefact of the influence of the presence of tributaries. River length was also identified as an important explanatory variable. There was a significant correlation $(p<0.01)$ between this variable and the number of tributaries ( $r_{\text {Pearson }}=0.67$ (LTrib) and $r_{\text {Pearson }}=0.64(\mathrm{STrib})$, data not shown), indicating that the number of tributaries increases with river length. However, the higher incidence of juvenile rainbow trout in tributaries relative to the main stem of four rivers with a self-sustaining population indicates that the importance of tributaries is not simply an artefact of the total length of available stream channel in the stream network. 
Surprisingly, the distance to the stocking areas had no significant effect on the presence of rainbow trout, probably because a more recent source of colonists has been established in Charlevoix (Thibault et al., 2009), outside the stocking zone. Multiple sources of colonists, including recently founded populations, may thus mask the expected relationship. Dams in the downstream $10 \mathrm{~km}$ did not prevent rainbow trout colonization, with rainbow trout being present in 9 out of the 19 rivers which had one or more dams. It is possible that rainbow trout presence had been detected downstream of these dams. Moreover, it is known that some adult rainbow trout have passed through a few dams using fish passages due to inadequate monitoring (SOGERM - Société de gestion de la rivière Matane, pers. communication).

Even if the climate model only explains a marginal portion of the variation in the presence of rainbow trout, climatic variables may nevertheless influence rainbow trout presence in rivers that are geomorphologically suitable. In the climate model, rainbow trout presence was positively related to spring and summer temperature (from April to September) and effective growing degree days (EGDD). Fausch (2007) predicted that rainbow trout required about 9001000 EGDD for successful recruitment. Almost all studied rivers reached this range, but higher degree days on average were found in rivers where rainbow trout was reported (1138.3 EGDD) than in rivers where it was not (1072.8 EGDD). The optimal temperature for reproduction ranges from $10-15{ }^{\circ} \mathrm{C}$ (Burgner et al., 1992), whereas the temperatures in the rivers in this study at the time of reproduction (mid-May to early-June in Quebec) tended to be less than this, with mean monthly temperatures varying from $3.2-10.1^{\circ} \mathrm{C}$ in May and from $8.2-13.9^{\circ} \mathrm{C}$ in June. The optimal temperature for adult growth and survival is approximately $21^{\circ} \mathrm{C}(\mathrm{Scott}$ and Crossman, 1973), whereas all rivers had mean monthly temperatures less than this throughout the year. However, moderate maximum summer water temperatures $\left(13-19{ }^{\circ} \mathrm{C}\right)$ can also support high trout densities (Molony, 2001). It is thus probable that rainbow trout presence was positively related to spring and summer temperatures because river temperatures were generally below the optimal levels for adult rainbow trout. Therefore, rivers with greater temperatures could support higher growth and survival rates. This also suggests that climatic warming could facilitate the establishment of rainbow trout in the rivers of Eastern Quebec over the next few decades (for rivers which have suitable geomorphological characteristics). The climate model also identified the impact of spring precipitations on species colonization, as peak flood date scored highly on the first principal component (Figure 3B): the later the peak flood date, the lower the rainbow trout occurrence. Fausch et al. (2001) found that the invasive success of rainbow trout is related to the match between the timing of fry emergence and low probability of flood disturbance. Blanchet (2007) observed an emergence period between June 26 and July 9 in the Malbaie River (for 2004 and 2005), one of the four rivers with an established self-supporting population of rainbow trout. In Eastern Quebec, the peak flood date occurs from May 1-17, long before the fry emergence period. Our results therefore suggest that high flow levels later in May could, instead of influencing fry survival, have an impact on spawning and egg deposition, which occurs 5 to 8 weeks before emergence.

\section{$>$ SCALE EFFECT}

Even if some climatic variables showed a slight relationship with rainbow trout presence, we expected a greater contribution of water temperature, flood regime and precipitation for explaining the presence of this invasive fish in Eastern Quebec rivers. One explanation for the marginal role of climatic factors might be the spatial scale used in this study. The area covered by our modelling was relatively small: there was less than $650 \mathrm{~km}$ between the most distant rivers. On the contrary, studies that have found a significant influence of the flood regime or temperature on the rainbow trout invasion success (e.g. Fausch, 2001; Fausch et al., 2007), have compared rivers located in much more distant regions (country scale). Thus, the climatic variation observed between Eastern Quebec Rivers may not be great enough to drive the rainbow trout invasion, as compared to geomorphological characteristics. 


\section{CONCLUSION}

A regional spatial and temporal scale survey allowed us to determine the distribution of the nonnative salmonid rainbow trout in Eastern Quebec. Adults have been found in several rivers of Eastern Quebec for many years, although self-established populations are at present found in only four rivers. Other lines of evidence suggest the existence of unknown established populations, especially in Gaspesia (Thibault et al., 2009, 2010). It therefore seems that the invasion is still in progress and our modelling showed that abiotic factors strongly influence this process. The presence of tributaries (especially larger ones) is the most important variable, followed by climatic variables such as warm temperatures (monthly means and degree days) and timing of the spring flooding period. As the founding of new populations continues, rivers characterised by these abiotic attributes can be expected to be colonized in the short term. In Eastern Quebec, the invasion of rainbow trout is a slow but persistent process. Dealing with this kind of ongoing invasion, whatever the species, poses several modelling challenges, such as small sample sizes (number of colonized rivers) and the use of presence/absence data instead of densities. We do not have the luxury to wait until the establishment of many new populations and new monitoring plans to improve our data base before deciding on management actions. Waiting for colonisation to procede inevitably weakens attempts to mitigate the invasion. It would be probably difficult to reverse the situation in the two Eastern Quebec rivers (Malbaie and Du Gouffre Rivers) that have supported established populations of rainbow trout for several decades. However, the identification of rivers with higher probabilities of future colonisation at least provides an opportunity for managers to undertake some proactive mesures, such as the installation of fish passage structures, to control the invasion process.

\section{ACKNOWLEDGEMENTS}

This work was funded by grants from the Natural Sciences and Engineering Research Council of Canada to J.J.D., the Réseau Aquaculture Québec to J.J.D. and C.A., the Centre Interuniversitaire de Recherche sur le Saumon Atlantique, and the Fédération Québécoise de la Faune. I.T. was supported by an Alexander Graham Bell Canada Graduate Scholarship (NSERC). We thank our collaborators that helped to collect rainbow trout data: Ministère des ressources naturelles et de la faune, Québec Pêche, Fédération québécoise pour le saumon Atlantique, Fédération des gestionnaires de rivières à saumon du Québec, the fieldwork team 2007 and all ZECs, organisations, sport and commercial fishers that participated in the sampling campaigns. We are greatfull to Dr Kurt D. Fausch for his usefull comments on an earlier version of the manuscript.

\section{REFERENCES}

Blanchet S., 2007. Interactions compétitives entre le saumon atlantique et la truite arc-en-ciel : aspects écologiques, sélectifs et adaptatifs. Ph.D. Thesis, Département de Biologie, Université Laval, Québec.

Boughton D.A., Gibson M., Yedor R. and Kelley E., 2007. Stream temperature and the potential growth and survival of juvenile Oncorhynchus mykiss in a southern California creek. Freshwat. Biol., 52, 1353-1364.

Burgner R.L., Light J.T., Margolis L., Okazaki T., Tautz A. and Ito S., 1992. Distribution and origins of steelhead trout (Oncorhynchus mykiss) in offshore waters of the North Pacific Ocean. International North Pacific Fisheries Commission, Bulletin $n^{\circ} 51$.

Cambray J.A., 2003. The global impact of alien trout species - a review; with reference to their impact in South Africa. African Journal of Aquatic Science, 28, 61-67.

Colautti R.I. and Maclsaac H.J., 2004. A neutral terminology to define 'invasive' species. Divers. Distrib., $10,135-141$.

Colautti R.I., Grigorovich I.A. and Maclsaac H.J., 2006. Propagule pressure: a null model for biological invasions. Biol. Invasions, 8, 1023-1037. 
Currie R.J., Bennett A.W. and Beitinger T.L., 1998. Critical thermal minima and maxima of three freshwater game fish species acclimated to constant temperature. Environ. Biol. Fishes, 51, 187-200.

DMTI Spatial, 2005. CanMap Water V2005.3, Markham, Ontario: DMTI Spatial Inc. Available at www.dmtispatial.com.

Dumont P., 1991. Les ensemencements de maskinongé, de truite brune et de truite arc-en-ciel dans les eaux de la plaine de Montréal. Colloque sur l'ensemencement, Conseil de l'aquiculture et des pêches du Québec, Sainte-Foy (Québec), 30-42.

Dumont P., Bergeron J.F., Dulude P., Mailhot Y., Rouleau A., Ouellet G. and Lebel J.-P., 1988. Introduced salmonids: where are they going in Quebec watersheds of the Saint-Laurent River? Fisheries, 13, 9-17.

Fausch K.D., 1988. Tests of competition between native and introduced salmonids in streams: What have we learned? Can. J. Fish. Aquat. Sci., 45, 2238-2246.

Fausch K.D., 2007. Introduction, establishment and effects of non-native salmonids: considering the risk of rainbow trout invasion in the United Kingdom. J. Fish Biol., 71, Suppl. D, 1-32.

Fausch K.D., Taniguchi Y., Nakano S., Grossman G.D. and Townsend C.R., 2001. Flood disturbance regimes influence rainbow trout invasion success among five Holarctic regions. Ecol. Appl., 11, 1438-1455.

Gard R. and Flittner G.A., 1974. Distribution and abundance of fishes in Sagehen Creek, California. J. Wildl. Manage., 38, 347-358.

Garside E.T. and Tait J.S., 1958. Preferred temperature of rainbow trout (Salmo gairdneri Richardson) and its unusual relationship to acclimation temperature. Can. J. Zool., 36, 563-567.

Hastie T. and Tibshirani R., 1990. Generalized Additive Models, Chapman and Hall, London.

High B., Peery C.A. and Bennett D.H., 2006. Temporary staging of Columbia River summer steelhead in coolwater areas and its effect on migration rates. Trans. Am. Fish. Soc., 135, 519-528.

Hornik K., 2007. The R FAQ, http://CRAN.R-project.org/doc/FAQ/R-FAQ.html.

Hosmer D.W. and Lemeshow S., 1989. Applied logistic regression, Wiley, New York.

Kerr S.J. and Lasenby T.A., 2000. Rainbow trout stocking in inland lakes and streams: An annoted bibliography and literature review, Fish and Wildlife Branch, Ontario Ministry of Natural Resources, Peterborough, Ontario.

Kolar C.S. and Lodge D.M., 2001. Progress in invasion biology: predicting invaders. Trends Ecol. Evol., 16, 199-204.

Laurenson L.B.J. and Hocutt C.H., 1985. Colonisation theory and invasive biota: the Great Fish River, a case study. Environ. Monit. Assess., 6, 71-90.

Lefler K., Gál J. and Demeter G., 2006. Effect of water temperature on the embryonic development and hatching results of rainbow trout (Oncorhynchus mykiss). Magyar Állatorvosok Lapja, 128, 565-569.

MacCrimmon H.R., 1971. World distribution of rainbow trout (Salmo gairdneri). Journal of the Fisheries Research Board of Canada, 28, 663-704.

MacKenzie D.I., Nichols J.D., Royle J.A., Pollock K.H., Bailey L.L. and Hines J.E., 2006. Occupancy estimation and modeling: Inferring patterns and dynamics of species occurrence, Elsevier, San Diego.

MAPAQ, 2005. Les zones piscicoles du Québec. Agriculture, Pêcheries et Alimentation du Québec, Québec.

Mitro M.G., Zale A.V. and Rich B.A., 2003. The relation between age-0 rainbow trout (Oncorhynchus mykiss) abundance and winter discharge in a regulated river. Can. J. Fish. Aquat. Sci., 60, 135139.

Molony B., 2001. Environmental requirements and tolerances of rainbow trout (Oncorhynchus mykiss) and brown trout (Salmo trutta) with special reference to Western Australia: A review. Fisheries Research Report of Western Australia, $\mathrm{n}^{\circ} 130$.

Mongeau J.-R., Leclerc J. and Brisebois J., 1980. La répartition géographique des poissons, les ensemencements, la pêche sportive et commerciale, les frayères et la bathymétrie du fleuve SaintLaurent dans le Bassin de La Prairie et les Rapides de Lachine. Ministère du Loisir, de la Chasse et de la Pêche, Service de l'Aménagement et de l'Exploitation de la Faune, Montréal (Québec).

Moyle P.B. and Light T., 1996. Biological invasions of freshwater: empirical rules and assembly theory. Biol. Conserv., 78, 149-161. 
Moyle P.B. and Marchetti M.P., 2006. Predicting invasion success: freshwater fishes in California as a model. BioScience, 56, 515-524.

Nelitz M.A., Maclsaac E.A. and Peterman R.M., 2007. A science-based approach for identifying temperature-sensitive streams for rainbow trout. N. Am. J. Fish. Manage., 27, 405-424.

Québec, 2000. Ministère des Ressources naturelles et de la Faune. St-Georges, Québec. Base de données topographiques du Québec , 1:20 000, feuille 21L/02-200-202, version 1.0, Québec : Ressources naturelles et de la Faune.

Quist M.C., Rahel F.J. and Hubert W.A., 2005. Hierarchical faunal filters: an approach to assessing effects of habitat and nonnative species on native fishes. Ecol. Freshwat. Fish, 14, 24-39.

Richards C.L., Bossdorf O., Muth N.Z., Gurevitch J. and Pigliucci M., 2006. Jack of all trades, master of some? On the role of phenotypic plasticity in plant invasion. Ecol. Lett., 9, 981-993.

SAS v9, 2001. Language Guide, SAS Institute Inc., Release 6.03, Cary, N.C.

Scott W.B. and Crossman E.J., 1973. Freshwater fishes of Canada. Office des recherches sur les pêcheries du Canada, Ottawa, Bulletin n 184.

Thibault I., 2010. Invasion de la truite arc-en-ciel (Oncorhynchus mykiss) dans l'Est du Québec. Ph.D. Thesis, Departement de biologie, Université Laval, Québec.

Thibault I., Bernatchez L. and Dodson J.J., 2009. The contribution of newly established populations to the dynamics of range expansion in a one-dimensional fluvial-estuarine system: rainbow trout (Oncorhynchus mykiss) in Eastern Quebec. Divers. Distrib., 15, 1060-1072.

Thibault I., Hedger R.D., Dodson J.J., Shiao J.-C., lizuka Y. and Tzeng W.-N., 2010. Anadromy and the dispersal of an invasive fish species (Oncorhynchus mykiss) in Eastern Quebec, as revealed by otolith microchemistry. Ecol. Freshwat. Fish., 19, 348-360.

Whoriskey F.G., Naiman R.J. and Heinermann P.H., 1981. Steelhead trout (Salmo gairdneri) on the North shore of the Gulf of St. Lawrence, near Sept-Îles, Québec. Can. J. Fish. Aquat. Sci., 38, 245-246.

Williamson M., 1996. Biological Invasions, Chapman \& Hall, London. 


\section{Appendix A - Univariate statistics for geomorphological variables (Tables A.I and A.II)}

\section{Annexe A - Statistiques univariées pour les variables géomorphologiques (Tableaux A.I et A.II)}

\section{Table A.I}

Results of the univariate analyses on untransformed geomorphological variables. Three variables (Sin, Dam and SZD) do not respect the Hosmer and Lemeshow criteria fixed at $p<0.25$ (in bold) to be included in a multivariate model.

\section{Tableau A.I}

Résultats des analyses univariées réalisées sur les variables géomorphologiques non transformées. Trois variables (Sin, Dam et SZD) ne respectent pas le critère d'Hosmer et Lemeshow, fixé à $p<0,25$ (en gras), pour être incluses dans un modèle multivarié.

\begin{tabular}{|l|c|c|c|c|c|}
\hline Variable & \multicolumn{2}{|c|}{ Test for variance equality } & \multicolumn{3}{|c|}{ Student test } \\
& $F$ value & $p>F$ & Method & $T$ value & $p>T$ \\
\hline MS & 1.21 & 0.55 & Pooled & 2.96 & $<0.01$ \\
\hline Sin & 1.92 & 0.03 & Satterthwaite & -1.19 & 0.24 \\
\hline MinE & 2.29 & $<0.01$ & Satterthwaite & -0.90 & 0.37 \\
\hline MaxE & 1.76 & 0.06 & Pooled & -3.24 & $<0.01$ \\
\hline Len & 1.40 & 0.29 & Pooled & -3.47 & $<0.01$ \\
\hline STrib & 3.64 & $<0.01$ & Satterthwaite & -4.97 & $<0.01$ \\
\hline LTrib & 5.22 & $<0.01$ & Satterthwaite & -6.23 & $<0.01$ \\
\hline Dam & 1.38 & 0.32 & Pooled & -0.16 & 0.87 \\
\hline SZD & 1.05 & 0.85 & Pooled & 0.71 & $\mathbf{0 . 4 8}$ \\
\hline
\end{tabular}

\section{Table A.II}

Transformation of the geomorphological variables for which the relationship with the logit was not linear. The mention "na" appears for excluded variables (refer to Table A.l). No transformation was necessary for the PCs (either in geomorphological or climatic models).

\section{Tableau A.II}

Transformation des variables géomorphologiques pour lesquelles la relation avec le logit n'était pas linéaire. La mention «na » apparaît pour les variables exclues (se référer au Tableau A.l). Aucune transformation n'était nécessaire pour les composantes principales (tant pour le modèle géomorphologique que climatique),

\begin{tabular}{|c|c|c|}
\hline Variable & Form of the relation & Transformation \\
\hline MS & quadratic & $\mathrm{MS} \mathrm{MS}^{2}$ \\
\hline Sin & linear & \\
\hline MinE & null & na \\
\hline MaxE & linear & \\
\hline Len & linear & \\
\hline STrib & linear & \\
\hline LTrib & $\begin{array}{c}\text { linear or } \\
\text { categoric }^{\S}\end{array}$ & $\begin{array}{c}{[0],[1-2] \text { and }[3+]} \\
{[0] \text { and }[1+]}\end{array}$ \\
\hline Dam & null & na \\
\hline SZD & null & na \\
\hline
\end{tabular}

$\S$ It was not clear which type of relation was the most significant, therefore we tested all (untransformed data and two categorizations). 


\section{Appendix B - Analyses of detectability (Tables B.I and B.II)}

\section{Annexe B : Analyses de détectabilité (Tableaux B.I et B.II)}

\section{Table B.I}

Description of the two variables used to evaluate the influence of the detection effort (targetted on Atlantic salmon) on the rainbow trout presence in 44 rivers located in Eastern Quebec. p-Values indicate significant univariate relationships with the presence of the exotic fish species.

\section{Tableau B.I}

Description des deux variables utilisées pour évaluer l'influence de l'effort de détection (associé au saumon atlantique) sur la présence de la truite arc-en-ciel dans 44 rivières situées dans l'est du Québec. Les valeurs de $p$ démontrent des relations univariées significatives avec la présence de l'espèce de poisson exotique.

\begin{tabular}{|l|c|c|c|c|}
\hline Variable & Abbreviation & Fisher p-value & Category & Description \\
\hline $\begin{array}{l}\text { Monitoring } \\
\text { effort }\end{array}$ & Mo_Ef & $<0.01$ & {$[0]$} & No effort \\
\hline Fishing & Fi_Ef & $<0.01$ & {$[1]$} & Presence of counting fence and/or visual counting by snorkelling \\
effort & & & {$[1]$} & No salmon fishing-day from 1984 to 2008 \\
& & & {$[2]$} & $1-1000$ salmon fishing-days from 1984 to 2008 \\
& & & {$[3]$} & $1001-5000$ salmon fishing-days from 1984 to 2008 \\
& & & {$[4]$} & $1001-10000$ salmon fishing-days from 1984 to 2008 \\
& & & {$[5]$} & $>500000$ salmon fishing-days from 1984 to 2008 \\
\hline
\end{tabular}

\section{Table B.II}

Significance and coefficients of the detection effort variables when included in the two most significant geomorphological models presented in Table II. Climatic model is not used since its contribution to explain the rainbow trout presence was marginal when compared to the geomorphological models.

\section{Tableau B.II}

Significativité et coefficients pour les variables associées à l'effort de détection, lorsqu'elles sont incluses dans les deux modèles géomorphologiques les plus significatifs présentés au Tableau II. Le modèle climatique n'a pas été considéré, car sa contribution pour expliquer la présence de la truite arc-en-ciel était marginale comparativement à celle des modèles géomorphologiques.

\begin{tabular}{|c|c|c|c|}
\hline Model ID & Variables & $\rho$-Value & $\beta$ estimate (SE) \\
\hline \multicolumn{4}{|c|}{ When the "monitoring effort" variable is added } \\
\hline \multirow[t]{2}{*}{ G1 } & LTrib & $<0.01$ & $0.95(0.29)$ \\
\hline & Mo_Ef [1 vs. 0] & 0.08 & $1.62(0.93)$ \\
\hline \multirow[t]{3}{*}{ G2 } & LTrib [1-2 vs. 0] & 0.03 & $2.74(1.27)$ \\
\hline & LTrib $[3+$ vs. 0] & $<0.01$ & $3.85(1.11)$ \\
\hline & Mo_Ef [1 vs. 0] & 0.06 & $1.86(0.98)$ \\
\hline \multicolumn{4}{|c|}{ When the "fishing effort" variable is added } \\
\hline \multirow[t]{6}{*}{ G1 } & LTrib & 0.03 & $0.88(0.40)$ \\
\hline & Fi_Ef [1 vs. 0] & 0.98 & $-10.21(339.70)$ \\
\hline & Fi_Ef [2 vs. 0] & 0.15 & $2.34(1.63)$ \\
\hline & Fi_Ef [3 vs. 0] & 0.74 & $0.61(1.82)$ \\
\hline & Fi_Ef [4 vs. 0] & 0.05 & $3.40(1.72)$ \\
\hline & Fi_Ef [5 vs. 0] & 0.96 & $13.09(288.70)$ \\
\hline \multirow[t]{7}{*}{ G2 } & LTrib [1-2 vs. 0] & 0.17 & $2.30(1.67)$ \\
\hline & LTrib [3+ vs. 0] & 0.02 & $3.64(1.58)$ \\
\hline & Fi_Ef [1 vs. 0] & 0.98 & $-9.60(339.70)$ \\
\hline & Fi_Ef [2 vs. 0] & 0.13 & $2.67(1.74)$ \\
\hline & Fi_Ef [3 vs. 0] & 0.58 & $1.03(1.86)$ \\
\hline & Fi_Ef [4 vs. 0] & 0.04 & $3.61(1.74)$ \\
\hline & Fi_Ef [5 vs. 0] & 0.97 & $13.68(330.30)$ \\
\hline
\end{tabular}

$\S$ In reference to IDs presented in Table II. 